\title{
Amino acid racemization in Quaternary foraminifera from the Yermak Plateau, Arctic Ocean
}

\author{
Gabriel West $^{1}$, Darrell S. Kaufman ${ }^{2}$, Francesco Muschitiello ${ }^{3}$, Matthias Forwick ${ }^{4}$, Jens Matthiessen ${ }^{5}$, \\ Jutta Wollenburg ${ }^{5}$, and Matt O'Regan ${ }^{1}$ \\ ${ }^{1}$ Department of Geological Sciences, Stockholm University, 10691 Stockholm, Sweden \\ ${ }^{2}$ School of Earth and Sustainability, Northern Arizona University, Flagstaff, AZ 86011, USA \\ ${ }^{3}$ Department of Geography, University of Cambridge, Cambridge, CB2 3EN, UK \\ ${ }^{4}$ Department of Geosciences, UiT The Arctic University of Norway, 9037 Troms $\varnothing$, Norway \\ ${ }^{5}$ Alfred Wegener Institute for Polar and Marine Research, 27570 Bremerhaven, Germany
}

Correspondence: Gabriel West (gabriel.west@geo.su.se)

Received: 11 June 2019 - Discussion started: 16 July 2019

Accepted: 25 October 2019 - Published: 18 November 2019
Abstract. Amino acid racemization (AAR) geochronology is a powerful tool for dating Quaternary marine sediments across the globe, yet its application to Arctic Ocean sediments has been limited. Anomalous rates of AAR in foraminifera from the central Arctic were reported in previously published studies, indicating that either the rate of racemization is higher in this area, or inaccurate age models were used to constrain the sediment ages. This study investigates racemization rates in foraminifera from three welldated sediment cores taken from the Yermak Plateau during the 2015 TRANSSIZ (TRansitions in the Arctic Seasonal Sea Ice Zone) expedition on RV Polarstern. D and L isomers of the amino acids aspartic acid (Asp) and glutamic acid (Glu) were separated in samples of the planktic foraminifer Neogloboquadrina pachyderma and the benthic species Cassidulina neoteretis to quantify the extent of racemization. In total, 241 subsamples were analysed, extending back to marine oxygen isotope stage (MIS) 7. Two previously published power functions, which relate the extent of racemization of Asp and Glu in foraminifera to sample age are revisited, and a comparison is made between the ages predicted by these calibrated age equations and independent geochronological constraints available for the cores. Our analyses reveal an excellent match between ages predicted by a global compilation of racemization rates for $N$. pachyderma and confirm that a proposed Arctic-specific calibration curve is not applicable at the Yermak Plateau. These results generally support the rates of AAR determined for other cold bottom water sites and fur- ther highlight the anomalous nature of the purportedly high rate of racemization indicated by previous analyses of central Arctic sediments.

\section{Introduction}

Dating Quaternary marine sediments from the Arctic Ocean has been a long-standing problem, and a number of studies (e.g. Backman et al., 2004; Stein, 2011; Alexanderson et al., 2014) highlight the challenges of establishing firm chronologies for these sediments. Assigning ages for the various lithostratigraphic units in Arctic Ocean sediments is, however, of paramount importance as the development of accurate age models is key to contextualize Arctic palaeoceanography within Earth's climate system.

Amino acid racemization (AAR) geochronology was first applied specifically to Arctic Ocean sediments in the pioneering studies of Sejrup et al. (1984) and later in that of Macko and Aksu (1986). Sejrup et al. (1984) used AAR results to challenge the prevailing view of slow $\left(\mathrm{mm} \mathrm{kyr}^{-1}\right)$ sedimentation rates (e. g. Clark, 1970) in the Arctic and warned that the existing age interpretations derived from bio- and magnetostratigraphy could be substantially flawed. On the other hand, Macko and Aksu (1986) found that AAR chronology of sediments from the Alpha Ridge supported the accepted ages established by the use of these two dating techniques, thus supporting arguments for slow sedimentation rates in this region. Due to the limitations - associated with small 
sample size and low temporal resolution - of these early studies, the application of AAR chronology for Arctic Ocean sediments decreased in the following years. However, major developments in AAR dating, such as the increased use of the more rapidly racemizing aspartic acid over isoleucine (e.g. Goodfriend et al., 1996) and the application of the reverse phase liquid chromatography to determine amino acid $\mathrm{D} / \mathrm{L}$ values in small samples (Kaufman and Manley, 1998) coupled with improvements in Arctic Ocean sediment chronostratigraphies (e.g. Jakobsson et al., 2001; Backman et al., 2008; O'Regan et al., 2008) have reignited the interest in AAR studies during the past decade.

Kaufman et al. (2008) related the extent of AAR in the polar foraminifera species Neogloboquadrina pachyderma, collected from various parts of the Arctic Ocean (Mendeleev Ridge, Lomonosov Ridge, Northwind Ridge), to sediment ages by developing a calibrated age equation for the past $150 \mathrm{kyr}$. This was followed by the study of Kaufman et al. (2013), who reported the results of AAR analysis of multiple foraminifera species from sediment cores taken in the Arctic, Atlantic, and Pacific oceans and defined a general rate of racemization at deep-sea sites. Both models relied on calibration of the rate of racemization of aspartic (Asp) and glutamic (Glu) acids by independent dating methods (such as radiocarbon dating and correlations with the orbitally tuned, stacked oxygen isotope record; Martinson et al., 1987), yet for the past $150 \mathrm{kyr}$, these two age equations produced significantly different ages for a given $\mathrm{D} / \mathrm{L}$ value. The global compilation of AAR showed that the rate of racemization in the Arctic Ocean was higher than expected in samples of $N$. pachyderma older than $35 \mathrm{ka}$, and this could not be explained by differences in the rate of AAR in $N$. pachyderma relative to other species. It remains to be seen whether the observed rates of racemization are anomalously high compared to other ocean basins or, alternatively, the age constraints for the studied Arctic Ocean cores are inaccurate. Sedimentary sequences with robust age control and satisfactory preservation of carbonate microfossils from the Arctic are required to further investigate this question.

Here we present the results of amino acid racemization analysis of planktic ( $N$. pachyderma) and benthic $(C$. neoteretis) foraminifera from samples of three well-dated sediment cores from the Yermak Plateau. The rates of racemization in the two species are compared, and the Arcticspecific (Kaufman et al., 2008) and global (Kaufman et al., 2013) calibrated age equations are used to estimate the ages of the samples. The calculated ages are compared with those derived from age models constructed by combining ${ }^{14} \mathrm{C}$ dating, oxygen isotope stratigraphy, and the correlation of environmental magnetic properties to the global benthic oxygen isotope record.

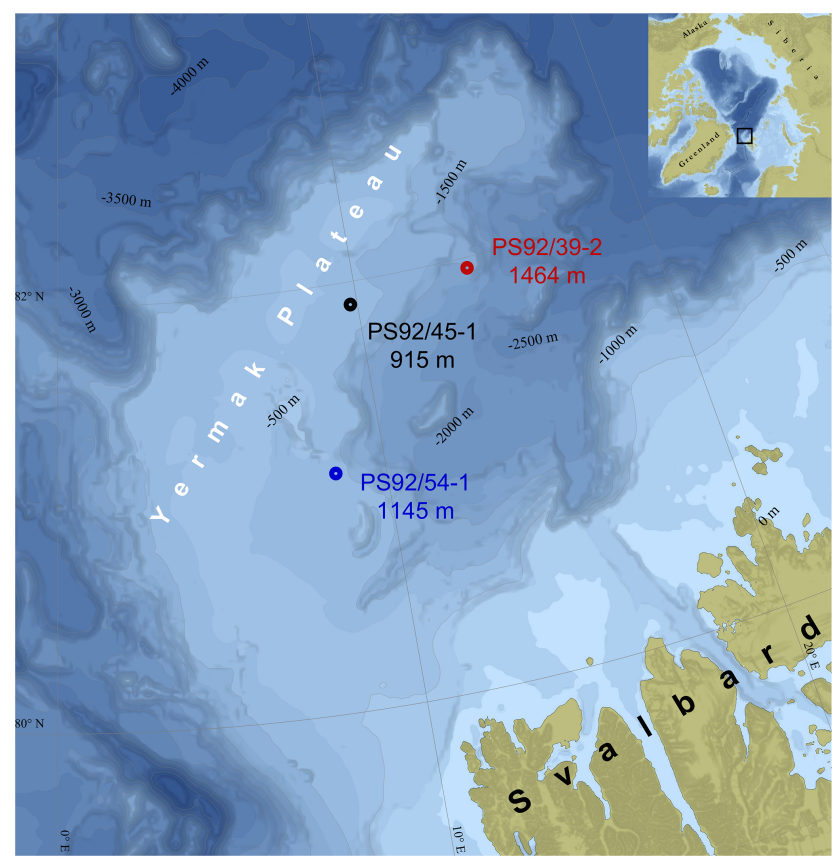

Figure 1. Locations of the studied cores and water depth at core sites. Basemap: IBCAO, Jakobsson et al. (2012).

\section{Materials and methods}

\subsection{Sample material and study area}

The analysed foraminifera samples were taken from three sediment cores (PS92/0039-2, PS92/0045-2 and PS92/54-1) recovered from the Yermak Plateau during the TRANSSIZ (TRansitions in the Arctic Seasonal Sea Ice Zone) expedition (19 May to 28 June 2015) on the research icebreaker RV Polarstern (PS92) (Table 1 and Fig. 1).

The Yermak Plateau, located north of the Svalbard archipelago, lies at the gateway to the central Arctic Ocean, in an area characterized by the interaction between Atlantic and Arctic waters. The cold surface layer is dominated by the polar foraminifer $N$. pachyderma, which has highest abundances in the top $200 \mathrm{~m}$ (Carstens and Wefer, 1992; Carstens et al., 1997; Pados and Spielhagen, 2014; Greco et al., 2019). Cassidulina neoteretis is one of the dominant benthic species in sediments from the Yermak Plateau (Bergsten, 1994; Wollenburg and Mackensen, 1998; Wollenburg et al., 2004), and its abundance is often associated with the presence of Atlantic water (Polyak and Solheim, 1994; Ślubowska et al., 2005).

The cores were recovered from water depths between 915 and $1464 \mathrm{~m}$ - in the Upper Polar Deep Water - far below the core of the warmer Atlantic layer, which typically sits between depths of 200 and $500 \mathrm{~m}$ (Jones, 2001). Potential temperature and salinity profiles from nearby CTD (conductivity-temperature-depth) stations illustrate the re- 
Table 1. Sediment cores analysed in this study.

\begin{tabular}{llrrrrr}
\hline Core & Core type & $\begin{array}{r}\text { Latitude } \\
\left({ }^{\circ} \mathrm{N}\right)\end{array}$ & $\begin{array}{r}\text { Longitude } \\
\left({ }^{\circ} \mathrm{E}\right)\end{array}$ & $\begin{array}{r}\text { Water } \\
\text { depth }(\mathrm{m})\end{array}$ & $\begin{array}{r}\text { Core } \\
\text { length }(\mathrm{m})\end{array}$ & $\begin{array}{r}\text { Bottom water } \\
\text { temperature }\left({ }^{\circ} \mathrm{C}\right)\end{array}$ \\
\hline PS92/39-2 & kastenlot core & 81.94983 & 13.82833 & 1464 & 8.600 & -0.76 \\
PS92/45-2 & gravity core & 81.89333 & 9.768833 & 915 & 5.195 & -0.25 \\
PS92/54-1 & gravity core & 81.123 & 8.466167 & 1145 & 4.145 & -0.43 \\
\hline
\end{tabular}

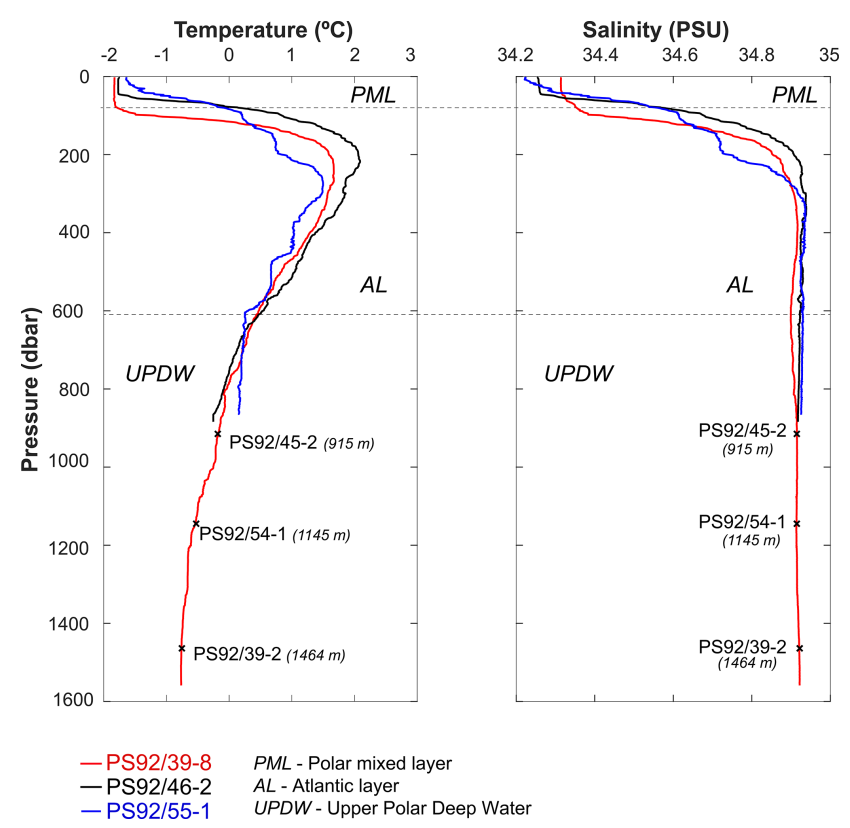

Figure 2. Potential temperature and salinity profiles of CTD stations (PS92/39-8, 46-2, and 55-1) nearest to the coring sites. CTD stations 46-2 and 55-1 did not sample the water depths of cores 45-2 and 54-1; thus the markers approximate where they would sit on the CTD profiles.

lationship between the coring sites and the local water masses (Fig. 2).

\subsection{Sample ages and quantification of age model uncertainties}

The age model of core PS92/39-2 was initially developed by Kremer et al. (2018), who used a combination of AMS ${ }^{14} \mathrm{C}$ dates, sedimentological correlations and the occurrence of the benthic foraminifer Pullenia bulloides as a stratigraphic marker for event $5.1(\sim 81 \mathrm{ka})$ in the polar North Atlantic (Haake and Pflaumann, 1989) and Arctic Ocean (Wollenburg et al., 2001). This age model was further developed by Wiers et al. (2019) by recalibrating the ${ }^{14} \mathrm{C}$ dates, integrating additional carbon and oxygen isotope data from foraminifera, and applying a correlation between environmental magnetic parameters (ratio of anhysteretic remanent susceptibility and bulk magnetic susceptibility) with the global stacked benthic foraminifera $\delta^{18} \mathrm{O}_{\mathrm{LR}}$ record of Lisiecki and Raymo (2005).
Wiers et al. (2019) extended this method to cores PS92/45-2 and PS92/54-1 (Figs. 3 and 4). The ability to correlate environmental magnetic parameters to the global benthic $\delta^{18} \mathrm{O}$ record in late Quaternary sediments from the Yermak Plateau was first proposed by Xuan et al. (2012), who also utilized ${ }^{14} \mathrm{C}$ dating and oxygen isotope measurements on planktic foraminifera.

To more rigorously provide a measure of the uncertainty inherent to the correlation-based age models, we applied an automated Monte Carlo algorithm for proxy-to-proxy stratigraphical alignment based on the assumption that changes in magnetic parameters $(\mathrm{kARM} / \mathrm{k}$, ratio of anhysteretic remanent susceptibility to bulk magnetic susceptibility) in our marine cores and variations in the $\delta^{18} \mathrm{O}_{\mathrm{LR}}$ stack are virtually synchronous. The algorithm used here consists of a modified and improved routine that builds upon previous work by Malinverno (2013) and Muschitiello et al. (2015) and Muschitiello (2016) and that has been widely used for synchronization of different palaeoclimate archives (e.g. Wohlfarth et al., 2018; Muschitiello et al., 2019). The method was designed to obtain a sample of optimal alignment functions that relates depth in one record to age (or depth) in another. The median of the samples gives the best correlation and their variability provides a measure of the uncertainty associated with the alignment, whereby the alignment function will have larger uncertainties where the match between the proxy time series is poorly constrained. Further details on adjustment of the age-depth model of Wiers et al. (2019) are contained in Appendix A.

\subsection{Sample preparation and analytical procedure}

Individual specimens of the foraminifera species $N$. pachyderma and $C$. neoteretis were picked from the $>63 \mu \mathrm{m}$ fraction of wet-sieved, oven-dried $\left(4 \mathrm{~h}\right.$ at $\left.30^{\circ} \mathrm{C}\right), 2 \mathrm{~cm}$ thick slices of sediment samples from core depths in which tests of the two species were abundant. The sediment slices were taken from u-channel samples that had been used for palaeomagnetic measurements, implying that the samples came from the central parts of the cores. This resulted in a total of 10 , 10 , and 5 sampled stratigraphic levels in cores PS92/39-2, PS92/45-2, and PS92/54-1, respectively. Seven core depths were sampled for both $N$. pachyderma and $C$. neoteretis in cores PS92/45-2 and PS92/54-1. Core PS92/39-2 was only sampled for $N$. pachyderma. 


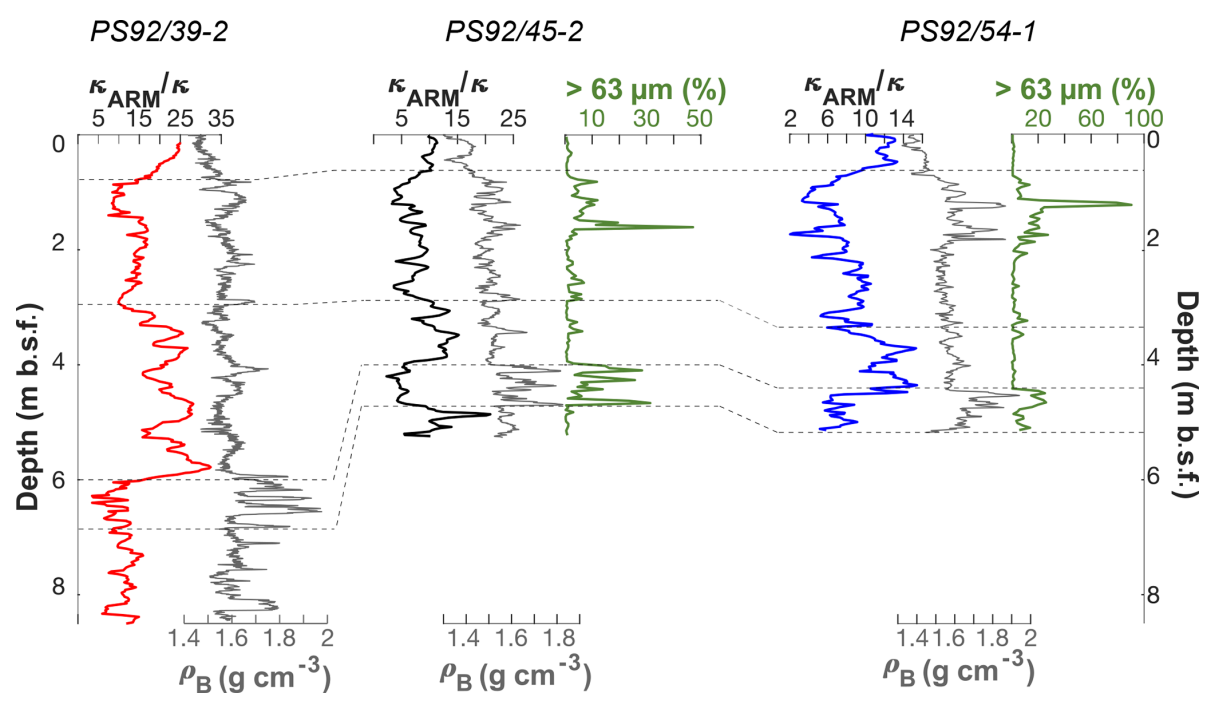

Figure 3. Lithostratigraphic correlation (on original depth scale) of sediment cores PS92/39-2, PS92/45-2, and PS92/54-1 based on Wiers et al. (2019). Dashed lines represent tie points. pB: bulk density.

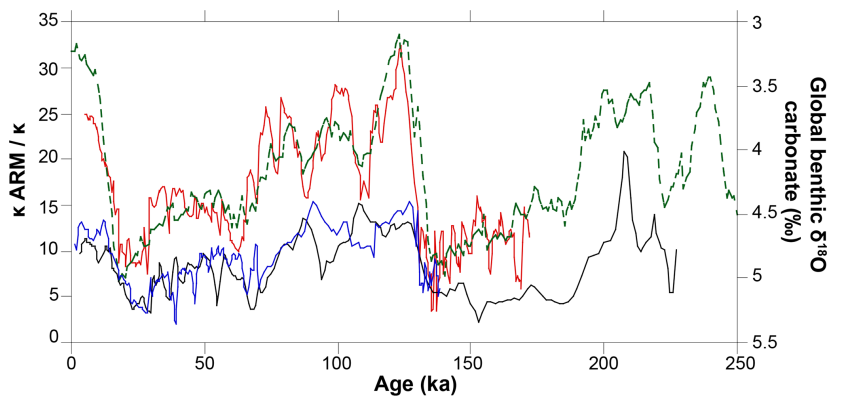

-- Global benthic $\bar{\delta}^{18} \mathrm{O}$ (Lisiecki and Raymo, 2005) - KARM/K PS92/39-2

- KARM/K PS92/45-2
- KARM/K PS92/54-1

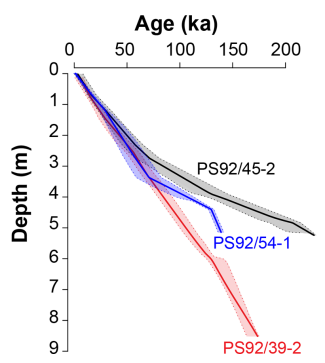

Figure 4. The age-depth models (Wiers et al., 2019) of the cores in this study are based on correlation of environmental magnetic parameters $(\mathrm{kARM} / \mathrm{k})$ and the global benthic $\delta^{18} \mathrm{O}$ stack of Lisiecki and Raymo (2005).

The foraminifera tests were first cleaned by sonication (approximately $1 \mathrm{~s}$ ) in a bath sonicator, then were immersed in $1 \mathrm{~mL}$ of $3 \% \mathrm{H}_{2} \mathrm{O}_{2}$ for $2 \mathrm{~h}$. Some samples required up to $4 \mathrm{~h}$ of immersion for a complete removal of organic matter. The tests were rinsed 3 times with reagent grade water (grade I) and dried under a laminar flow hood. In order to create subsamples for each sampled core depth, 7-12 tests were picked (minimum 7 tests for C. neoteretis and minimum 10 for $N$. pachyderma) and placed in micro-reaction hydrolysis vials pre-sterilized by heating at $550^{\circ} \mathrm{C}$. The number of subsamples within a sample was constrained by the number of available tests and their level of preservation in a particular sample. To dissolve the tests, $8 \mu \mathrm{L}$ of $6 \mathrm{M} \mathrm{HCl}$ was added to the vials, and the solution was sealed under $\mathrm{N}_{2}$ gas. The subsamples were hydrolysed at $110^{\circ} \mathrm{C}$ for $6 \mathrm{~h}$ in order to convert the original protein present in the tests into free amino acids. Following hydrolysis, the subsamples were evaporated in a vacuum desiccator. A total of $4 \mu \mathrm{L}$ of $0.01 \mathrm{M} \mathrm{HCl}$ with $10 \mu \mathrm{M} \mathrm{L}$ homoarginine spike was added to the evaporate, and the subsamples were then injected onto a high-performance liquid chromatograph (HPLC). All measurements were performed at the Amino Acid Geochronology Laboratory, Northern Arizona University. The HPLC instrumentation and procedure used are described by Kaufman and Manley (1998). Interlaboratory standards (Wehmiller, 1984; Table 2) were analysed to monitor instrument performance.

The extent of amino acid racemization was determined by analysing the peak-area ratio of $\mathrm{D}$ and $\mathrm{L}$ enantiomers (nine amino acids measured in total). Data analysis focused on Asp and Glu, as these amino acids are abundant in foraminifera protein and among the best-resolved chromatographically (e.g. Kaufman et al., 2013), and they provide the basis of previous calibrated age equations.

\section{Results}

A total of 32 foraminifera samples (10 from core PS92/39-2, 13 from core PS92/45-1, and 9 from core PS92/54-1) sub- 
Table 2. Summary of aspartic acid and glutamic acid mean D/L values (following data screening) and independent ages (based on Wiers et al., 2019) of samples analysed in this study; $n$ : number of subsamples analysed; ex: number of excluded subsamples. Values in bold are mean D/L values that show depth reversals. Interlaboratory standards (ILC A, B, C) analysed during the course of this study are also shown.

\begin{tabular}{|c|c|c|c|c|c|c|c|c|c|c|}
\hline & & Depth & Age & & Number & $\mathrm{D} / \mathrm{L}$ & & $\mathrm{D} / \mathrm{L}$ & & \\
\hline Lab ID & Core & (m b.s.f.) & (ka) & $n$ & ex & of tests & Asp & $\sigma$ & Glu & $\sigma$ \\
\hline \multicolumn{11}{|c|}{ Neogloboquadrina pachyderma } \\
\hline 15544 & PS92/39-2 & 0.20 & 6.7 & 7 & 6 & 10 & 0.121 & - & 0.056 & - \\
\hline 15545 & PS92/39-2 & 0.35 & 8.9 & 4 & 4 & 10 & - & - & - & - \\
\hline 15546 & PS92/39-2 & 1.50 & 30.8 & 7 & 3 & 10 & 0.234 & 0.018 & 0.082 & 0.010 \\
\hline 15547 & PS92/39-2 & 3.00 & 64.2 & 8 & 0 & 10 & 0.258 & 0.025 & 0.103 & 0.021 \\
\hline 15548 & PS92/39-2 & 3.80 & 80.4 & 10 & 2 & 10 & 0.233 & 0.016 & 0.095 & 0.015 \\
\hline 15549 & PS92/39-2 & 5.81 & 126.3 & 9 & 5 & 10 & 0.272 & 0.063 & 0.110 & 0.035 \\
\hline 15550 & PS92/39-2 & 6.51 & 139.2 & 9 & 1 & 10 & 0.313 & 0.014 & 0.153 & 0.015 \\
\hline 15551 & PS92/39-2 & 7.21 & 150.8 & 10 & 6 & 10 & 0.298 & 0.016 & 0.118 & 0.016 \\
\hline 15552 & PS92/39-2 & 8.31 & 168.5 & 10 & 5 & 10 & 0.283 & 0.021 & 0.111 & 0.015 \\
\hline 15553 & PS92/39-2 & 8.41 & 170.1 & 10 & 4 & 10 & 0.329 & 0.017 & 0.169 & 0.013 \\
\hline 16814 & PS $92 / 45-2$ & 1.20 & 29.8 & 9 & 3 & 10 & 0.190 & 0.012 & 0.085 & 0.009 \\
\hline *16815 & PS92/45-2 & 1.59 & 39.5 & 11 & 0 & 10 & 0.195 & 0.008 & 0.084 & 0.007 \\
\hline * 16817 & PS $92 / 45-2$ & 3.12 & 90.1 & 8 & 4 & 10 & 0.269 & 0.019 & 0.124 & 0.027 \\
\hline 16818 & PS $92 / 45-2$ & 4.13 & 147.8 & 7 & 3 & 10 & 0.345 & 0.014 & 0.176 & 0.017 \\
\hline$* 17531$ & PS $92 / 45-2$ & 4.45 & 171.8 & 11 & 0 & 12 & 0.351 & 0.027 & 0.186 & 0.029 \\
\hline 16819 & PS92/45-2 & 4.73 & 194.9 & 6 & 2 & 10 & 0.362 & 0.023 & 0.189 & 0.016 \\
\hline * 16822 & PS92/54-1 & 1.79 & 40.1 & 7 & 1 & 10 & 0.166 & 0.011 & 0.070 & 0.009 \\
\hline *16826 & PS92/54-1 & 4.66 & 132.3 & 15 & 7 & 12 & 0.395 & 0.010 & 0.224 & 0.010 \\
\hline$* 16827$ & PS92/54-1 & 4.94 & 135.8 & 6 & 1 & 10 & 0.358 & 0.035 & 0.175 & 0.040 \\
\hline *16828 & PS92/54-1 & 5.1 & 137.8 & 4 & 1 & 10 & 0.345 & 0.018 & 0.186 & 0.020 \\
\hline \multicolumn{11}{|c|}{ Cassidulina neoteretis } \\
\hline 17315 & PS92/45-2 & 1.04 & 25.4 & 7 & 1 & 7 & 0.121 & 0.003 & 0.035 & 0.002 \\
\hline 17316 & PS $92 / 45-2$ & 1.39 & 34.5 & 2 & 1 & 7 & 0.159 & - & 0.055 & - \\
\hline *17317 & PS $92 / 45-2$ & 1.59 & 39.5 & 7 & 1 & 7 & 0.167 & 0.010 & 0.055 & 0.006 \\
\hline 17318 & PS $92 / 45-2$ & 1.75 & 43.5 & 3 & 2 & 7 & 0.189 & - & 0.070 & - \\
\hline *17319 & PS $92 / 45-2$ & 3.12 & 90.1 & 8 & 2 & 10 & 0.274 & 0.021 & 0.103 & 0.007 \\
\hline 17320 & PS92/45-2 & 4.17 & 150.8 & 7 & 3 & 7 & 0.341 & 0.017 & 0.160 & 0.017 \\
\hline$* 17321$ & PS92/45-2 & 4.45 & 171.8 & 10 & 3 & 10 & 0.277 & 0.022 & 0.154 & 0.025 \\
\hline 17322 & PS92/54-1 & 1.47 & 34.2 & 5 & 0 & 7 & 0.175 & 0.012 & 0.068 & 0.011 \\
\hline$* 17323$ & PS92/54-1 & 1.79 & 40.1 & 6 & 0 & 7 & 0.154 & 0.004 & 0.055 & 0.003 \\
\hline *17324 & PS92/54-1 & 4.66 & 132.3 & 7 & 2 & 7 & 0.319 & 0.012 & 0.165 & 0.023 \\
\hline *17325 & PS92/54-1 & 4.94 & 135.8 & 6 & 2 & 7 & 0.326 & 0.017 & 0.168 & 0.018 \\
\hline$* 17326$ & PS92/54-1 & 5.1 & 137.8 & 5 & 0 & 7 & 0.304 & 0.012 & 0.155 & 0.015 \\
\hline \multicolumn{11}{|c|}{ Interlaboratory standards } \\
\hline ILC-A & N/A & N/A & N/A & N/A & N/A & N/A & 0.412 & & 0.225 & \\
\hline ILC-B & N/A & N/A & N/A & N/A & N/A & N/A & 0.718 & & 0.453 & \\
\hline ILC-C & N/A & N/A & N/A & N/A & N/A & N/A & 0.842 & & 0.845 & \\
\hline
\end{tabular}

* Samples marked with an asterisk are from core depths sampled for both Neogloboquadrina pachyderma and Cassidulina neoteretis. N/A: not applicable.

divided into 241 subsamples (average: 7.5 subsamples per sample) were analysed. The average number of foraminifera tests per subsample was 10.2 for N. pachyderma and 7.5 for C. neoteretis (Table 2). The results of amino acid analysis of all subsamples are contained in Table S1 in the Supplement.
In order to assess whether subsample size had a significant influence on the resulting $\mathrm{D} / \mathrm{L}$ values, a further 47 subsamples of the foraminifer $N$. pachyderma were taken, each with 20 individual tests, from stratigraphic depths already sampled (subsamples with 10 tests). The results of this analysis were then compared with 42 subsamples that comprised 10 
tests. No statistically significant difference could be observed at the 0.01 probability level (the details of this analysis are contained in the Supplement).

Outliers were removed by following the screening process of Kosnik and Kaufman (2008):

1. Subsamples with L Ser/L Asp values greater than 0.8 were excluded, as this could be an indicator of contamination by modern amino acids.

2. The positive covariance of Asp and Glu acid D/L values in foraminifera is well known (e.g. Hearty et al., 2004; Kosnik and Kaufman, 2008); subsamples that deviated from the expected trend were excluded (Fig. 5).

3. Remaining subsamples with $\mathrm{D} / \mathrm{L}$ Asp or $\mathrm{D} / \mathrm{L}$ Glu values outside the $2 \sigma$ of the sample mean were rejected to emphasize the central tendency of the data.

This screening process resulted in the rejection of 68 subsamples, equivalent to $28.2 \%$ of all subsamples. The overall rejection rate is higher than for most other studies as summarized by Kaufman et al. (2013), although in this study, subsamples from core 39-2 account for over half (53\%) of all rejected subsamples, despite only $35 \%$ of all subsamples being taken from this core. Only $18.8 \%$ - typical of previous studies - of the subsamples from core 45-2 was rejected, and this core provided $40 \%$ of all subsamples.

Asp and Glu D/L values show an increasing trend with depth for both foraminifera species (Fig. 6) in all cores. D/L values of Asp and Glu in core PS92/39-2 are lower at equivalent depths below seafloor than compared to PS92/452 and PS92/54- 1 when samples from below $3 \mathrm{~m}$ are considered. Eight of the 32 samples exhibit mean Asp D/L values in reverse stratigraphic order (highlighted with bold in Table 2). Six of the reversed values overlap within $2 \sigma$ errors with the sample from shallower depths, and only two mean Asp D/L values from C. neoteretis samples in core PS92/452 (at $4.45 \mathrm{~m}$ ) and in core PS92/54-1 (at $1.79 \mathrm{~m}$ ) lack such an overlap. Mean D/L Glu values also exhibit stratigraphically reversed values in these samples, with overlaps within the error range of the overlying sample.

Mean D/L values of Asp and Glu are generally higher for $N$. pachyderma than for $C$. neoteretis for samples from the same depth (Table 2). This difference can be observed in both cores PS92/45-2 and PS92/54-1. It is difficult to quantify the differences in racemization rates between the two species, as little data are available for an extensive comparison, and some stratigraphic levels suffer from reversed $\mathrm{D} / \mathrm{L}$ values. However, as a basic approximation, a plot of $N$. pachyderma versus $C$. neoteretis mean $\mathrm{D} / \mathrm{L}$ values implies that Asp racemizes approximately $17 \%$ faster in $N$. pachyderma than in $C$. neoteretis, while Glu racemizes about $23 \%-26 \%$ faster in N. pachyderma (Fig. 7).

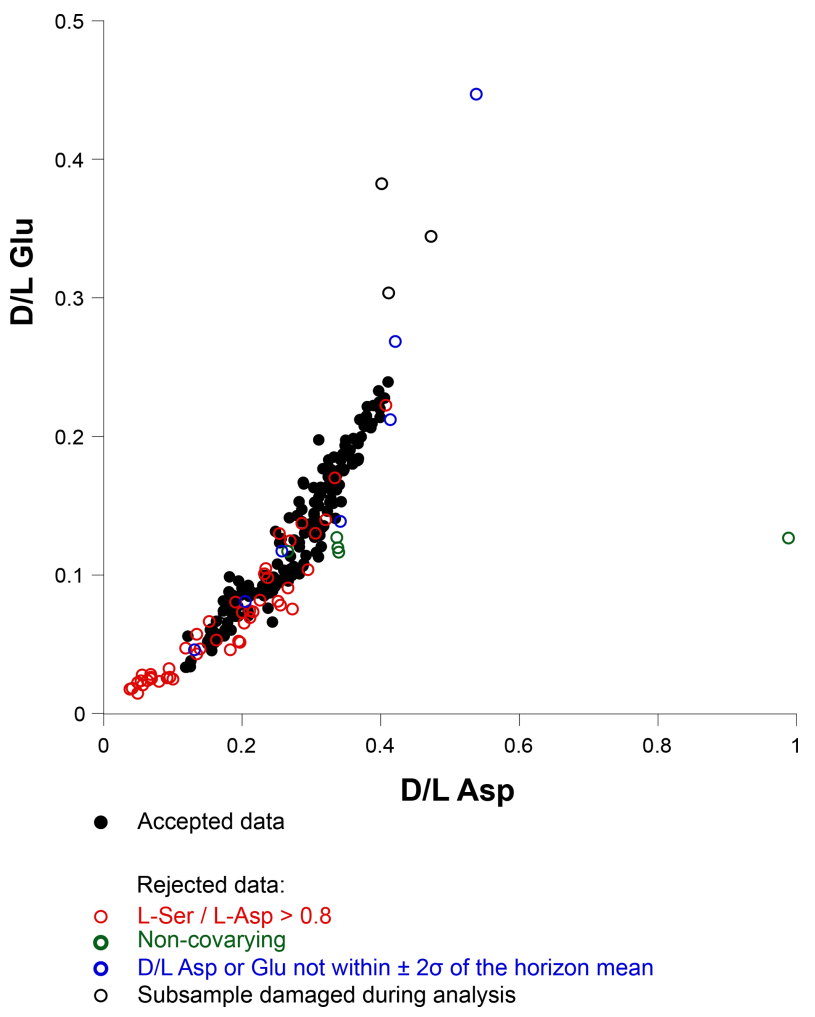

Figure 5. Covariance of aspartic acid and glutamic acid D/L values in all subsamples. Open symbols indicate rejected results, with the rejection criterion indicated by the symbol colour.

\section{Discussion}

\subsection{Relation between $D / L$ values and depth and inter-specific differences}

The extent of racemization generally increases with depth in both $N$. pachyderma and $C$. neoteretis samples, and this conforms to the expected diagenetic behaviour of amino acids in foraminifera. Eight samples have stratigraphically reversed mean D/L Asp and Glu values, but six of these values overlap within the $2 \sigma$ uncertainty envelope with the overlying sample.

For a given sediment depth, the extent of racemization in $N$. pachyderma samples is lower in PS92/39-2 below $3 \mathrm{~m}$ than in the other two cores (Fig. 6). This is consistent with the higher sedimentation rates in PS92/39-2 below $3 \mathrm{~m}$, compared to the other two cores, based on the independent age control of Wiers et al. (2019).

Differences in the rates of AAR (16\% for Asp and $23 \%-$ $26 \%$ for Glu - Fig. 7) between N. pachyderma and $C$. neoteretis tests from the same depths are similar to those documented in other AAR studies (e.g. King and Neville, 1977; Kaufman et al., 2013). Little is known about the extent and causes of the differences in racemization rates in these two species, but differences of similar magnitude between $\mathrm{D} / \mathrm{L}$ values of different taxa were previously reported in the lit- 

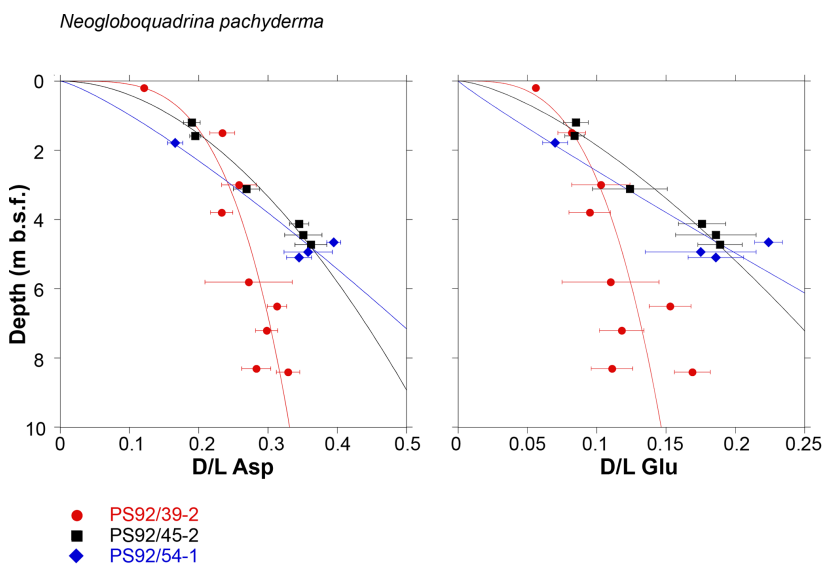

Cassidulina neoteretis
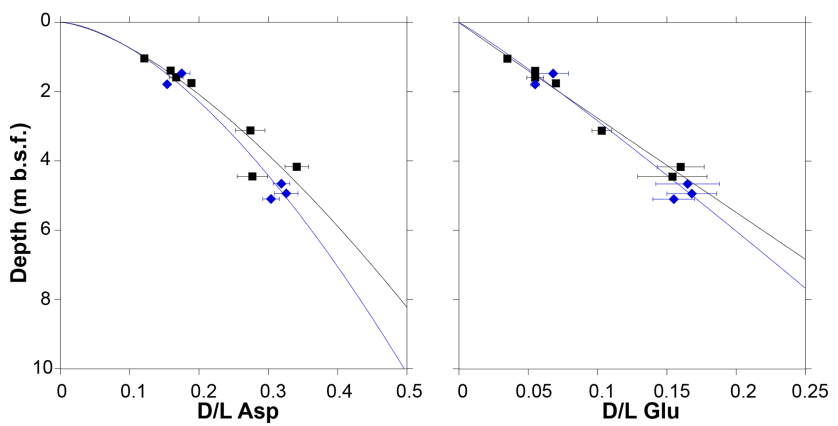

Figure 6. Extent of racemization (mean D/L in aspartic acid and glutamic acid) in samples of $N$. pachyderma and $C$. neoteretis plotted against depth in sediment cores PS92/39-2, PS92/45-2, and PS92/54-1. Error bars represent $\pm 1 \sigma$ deviation from the sample mean. Least square regression lines (power fit) are shown for all cores. Data listed in Table 2.

erature. For example, Kaufman et al. (2013) found that Asp racemized $12 \%-16 \%$ faster in Pulleniatina obliquiloculata than in N. pachyderma. As N. pachyderma and C. neoteretis are amongst the most commonly occurring planktic and benthic foraminifera species in the Arctic, the quantification of the relative rates of racemization between the two species will aid future AAR studies in the Arctic and could be augmented by future laboratory heating experiments.

Stratigraphically reversed $\mathrm{D} / \mathrm{L}$ Asp values, which do not overlap within the $2 \sigma$ uncertainty, only appear in $C$. neoteretis samples. One such reversal is in core PS92/45-2, in sample UAL17321 from $4.45 \mathrm{~m}$ core depth (total core length: $5.20 \mathrm{~m}$ ). In this sample the mean $\mathrm{D} / \mathrm{L}$ Asp value of 0.277 $(\sigma=0.022)$ is essentially equal to the mean value of 0.274 $(\sigma=0.021)$ from $3.12 \mathrm{~m}$ depth. It is difficult to explain the origin of the stratigraphically reversed mean values in the $C$. neoteretis samples. Sediment mixing (e.g. bioturbation, reworked material entrained in sea ice) offers one possible explanation and may account for reversals on decimetre scales, but it seems less likely that metre-scale downward mixing which would be required to explain the reversal discussed in
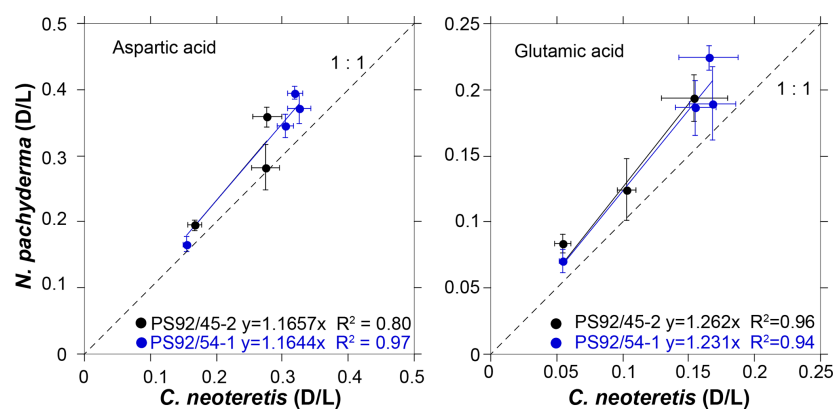

Figure 7. Extent of racemization (D/L) for aspartic and glutamic acids in $N$. pachyderma versus $C$. neoteretis samples from cores PS92/45-2 and PS92/54-1, with linear regression and line of equality.

PS92/45-2 - occurs. Icebergs are capable of extensive sediment reworking, but shipboard parasound and multibeam data show that the coring sites were free from iceberg scouring. The excellent correlation between the records precludes the possibility of large erosional events that could have removed or reworked sediments.

However, the small number (7) of foraminifera tests used in subsamples of $C$. neoteretis could also make the $\mathrm{D} / \mathrm{L}$ values more susceptible to variations in individual tests. For example, Lougheed et al. (2018) recently highlighted the large heterogeneity in the age distribution of foraminifera obtained from discrete depth intervals using ${ }^{14} \mathrm{C}$ dating of single foraminifera.

\subsection{Relation between D/L values and sample age}

A biplot of $\mathrm{D} / \mathrm{L}$ values against sample ages reveals that, as expected, the rate of Asp and Glu racemization is higher in younger samples and decreases with sample age as the reaction progresses towards equilibrium (Fig. 8). D/L values increase in a predictable manner over time as shown by least square regression power curves fitted to the mean $\mathrm{D} / \mathrm{L}$ Asp and Glu values for each of the cores. An exceptionally good fit for N. pachyderma samples is achieved in core PS92/452 (with $R^{2}$ values of 0.99 and 0.98 for D/L Asp and Glu, respectively; for individual regression lines see Fig. S1). In C. neoteretis samples, both Asp and Glu appear to racemize at similar rates in cores PS92/45-2 and PS92/54-1. Dissimilar $\mathrm{D} / \mathrm{L}$ Asp and Glu value between samples of comparable ages from different cores may originate from differences in sedimentation rates between the cores, variable post-depositional environmental factors, including differences in geothermal gradients, or variable diagenetic processes. These are discussed in more detail below.

\subsection{Palaeotemperature and other possible effects}

In monospecific foraminifera samples, the rate of racemization is often considered to be primarily controlled by the inte- 



Figure 8. Mean D/L values of aspartic and glutamic acids plotted against the independent ages of Wiers et al. (2019) for $N$. pachyderma and C. neoteretis samples from cores PS92/39-2, PS92/45-2, and PS92/54-1. Ages predicted (based on D/L Asp and Glu values) by the globally calibrated age equation of Kaufman et al. (2013) and the Arctic-specific age equation (Kaufman et al., 2008) are also displayed for reference. Error bars represent $\pm 1 \sigma$ deviation from the mean $\mathrm{D} / \mathrm{L}$ value of the sample and age uncertainty.

grated post-depositional temperature (Kaufman et al., 2013). Therefore, if the $\mathrm{D} / \mathrm{L}$ value and age of a sample are known, the AAR age equation can be solved for palaeotemperatures. Here we provide a rudimentary estimation of the difference in the effective diagenetic temperatures required to account for the offset between known-age-equivalent $\mathrm{D} / \mathrm{L}$ values between the coring sites. To achieve this, we relied on the temperature equation originally derived by Kaufman (2006) using simple power law kinetics for Asp in the foraminifera species, Pulleniatina obliquiloculata, and increased the $\mathrm{D} / \mathrm{L}$ values of our $N$. pachyderma samples by $16 \%$ to account for the lower rate of racemization in this taxon, as established by Kaufman et al. (2013). For comparison between the three core sites, we determined the approximate $\mathrm{D} / \mathrm{L}$ Asp values predicted by power-fit functions for each core at $150 \mathrm{ka}$; then the effective diagenetic temperatures integrated over the past $150 \mathrm{kyr}$ were derived from the temperature equation. The absolute derived temperatures need to be interpreted with caution, as no formal assessment of the racemization kinetics in N. pachyderma and an assessment of the uncertainties as-
Table 3. Approximate effective diagenetic temperatures at the three core sites integrated over the past $150 \mathrm{kyr}\left({ }^{\circ} \mathrm{C}\right)$.

\begin{tabular}{lrr}
\hline & $\begin{array}{r}\text { Estimated effective } \\
\text { diagenetic temperatures } \\
\text { over the past } 150 \mathrm{kyr}\left({ }^{\circ} \mathrm{C}\right)\end{array}$ & $\begin{array}{r}\text { Approximate average } \\
\text { sedimentation rate } \\
\text { during MIS 5 }\left(\mathrm{cm} \mathrm{kyr}^{-1}\right)\end{array}$ \\
\hline PS92/39-2 & $+4.2 \pm 0.8$ & 4.5 \\
PS92/45-2 & $+5.8 \pm 0.8$ & 2 \\
PS92/54-1 & $+8.2 \pm 0.8$ & 1.9 \\
\hline
\end{tabular}
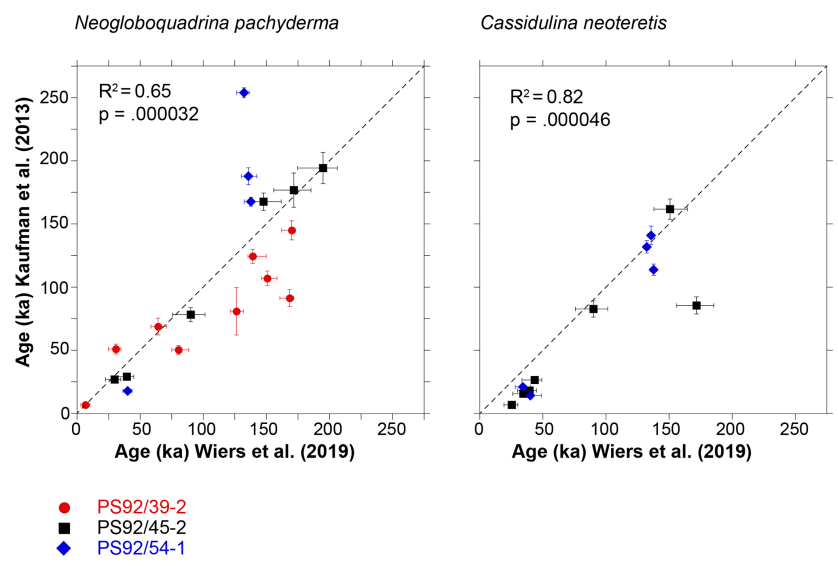

Figure 9. Comparison of sample ages for the two foraminifera taxa as predicted by the globally calibrated age equation of Kaufman et al. (2013) based on D/L Asp values and ages assigned to the samples based on the age model developed by Wiers et al. (2019), with line of equality.

sociated with these were completed. Furthermore, there are a number of complicating factors to these temperature estimates that are discussed below. However, relative temperature differences between the sites are likely still meaningful. The results imply that temperature differences $(\Delta T)$ of $\sim 1.6-4.0^{\circ} \mathrm{C}$ are required to account for the observed differences in racemization rates between the cores over the past $150 \mathrm{kyr}$ (Table 3). Details on palaeotemperature calculations are contained in the Supplement.

It is important to emphasize that AAR palaeotemperature estimates can only provide a measure of the long-term average post-depositional temperature, rather than the temperature of the water during calcification. The estimated difference in effective diagenetic temperatures between PS92/39-2 and PS92/54-1 $\left(4 \pm 1.6^{\circ} \mathrm{C}\right)$ cannot be easily accounted for by changes in bottom water temperatures alone. Modern bottom water temperatures at the three coring locations are relatively similar (between -0.25 and $-0.76^{\circ} \mathrm{C}$ ) (Table 1), although we do not know how similar these remained across glacial cycles. Presently the coring sites are beyond the reach of the warm $\left(>0.5^{\circ} \mathrm{C}\right)$ Atlantic layer (Fig. 2), which would need to be at significantly greater depths to generate such a large spread in the effective diagenetic temperatures of the coring sites. It is unclear how this could have happened in the past, 
and we do not see it as a plausible explanation for the apparent differences in calculated effective diagenetic temperatures.

Apart from differences in bottom water temperatures, differences in the geothermal gradient among sites could also impact the palaeotemperature signal. Unfortunately, no direct measurements of heat flow were obtained at the coring stations during TRANSSIZ and existing heat flow data from the Yermak Plateau are relatively sparse (Okay and Crane, 1993; Shephard et al., 2018). Existing measurements do indicate that regions of the Yermak Plateau are characterized by relatively high heat flow $\left(>100 \mathrm{~mW} \mathrm{~m}^{-2}\right)$, but with considerable spatial variability. Most measurements lie in the range of 50 to $100 \mathrm{~mW} \mathrm{~m}^{-2}$ (Shephard et al., 2018). If we use a thermal conductivity of $1.17 \mathrm{~W} \mathrm{mK}^{-1}$, reported from measurements on a core obtained from the Yermak Plateau (Shephard et al., 2018), heat flow of $50-100 \mathrm{~m} \mathrm{Wm}^{-2}$ translates into geothermal gradients of 43 to $85^{\circ} \mathrm{C} \mathrm{km}^{-1}\left(0.043\right.$ to $\left.0.085^{\circ} \mathrm{C} \mathrm{m}^{-1}\right)$. At a depth of $6 \mathrm{~m}$ below the seafloor, this range of geothermal gradients would amount to a present-day in situ temperature difference of only $0.25^{\circ} \mathrm{C}$. Thus, it also seems unlikely that local heat flow variations would significantly affect rates of racemization at the shallow sediment depth of these samples.

Sejrup and Haugen (1994) have theorized that variations in post-depositional microbial activity could have a profound impact on AAR and that the extent of microbial activity is related to sedimentation rates. Shells deposited in settings with low sedimentation rates could have been exposed longer to microbial activity at the seabed than shells that were buried rapidly and therefore more rapidly removed from the taphonomically active zone. Such increased exposure could result in a higher degree of protein and amino acid degradation in the early diagenetic phase, giving rise to higher initial $\mathrm{D} / \mathrm{L}$ values. The sedimentation rate in core PS92/39-2 is estimated to be around $4.5 \mathrm{~cm} \mathrm{kyr}^{-1}$ during marine oxygen isotope stage (MIS) 5 (assigned to the depth interval between $3.5-6 \mathrm{~m}), 2.5$ times that of the sedimentation rate at the other two core sites (Table 3 ). The comparatively lower $\mathrm{D} / \mathrm{L}$ values in core PS92/39-2 could reflect the faster burial and thereby better preservation of indigenous proteins in tests from the 3.5-6 m depth interval, yet the exact mechanisms of microbially mediated racemization remain unresolved. Currently we lack sufficient data to more fully explore the reasons for inter-site offsets in the AAR rates.

\subsection{Comparing AAR age models}

In order to assess the validity of the previously derived Arctic-specific (Kaufman et al., 2008) and globally calibrated (Kaufman et al., 2013) age equations at the Yermak Plateau, ages predicted by the two models were generated using the mean D/L Asp and Glu values from N. pachyderma and C. neoteretis tests in this study (Table 4). No ages using the Arctic-specific age equation were generated for C. neoteretis samples, as this calibration is based on AAR in N. pachyderma tests only. Ages predicted by the models were plotted against the corresponding $\mathrm{D} / \mathrm{L}$ values and displayed for reference in the biplot of $\mathrm{D} / \mathrm{L}$ values against sample age (Fig. 8). Age uncertainties were derived using the intra-sample variability $( \pm 1 \sigma)$ propagated through the age equations.

Modelled ages generated using the globally calibrated age equation of Kaufman et al. (2013) and mean D/L Asp values in $N$. pachyderma are most similar to the sample ages of Wiers et al. (2019) (Fig. 8). The Arctic-specific age equation of Kaufman et al. (2008) results in significantly younger ages than those based on the Wiers et al. (2019) age model (Fig. 8). This implies that the Arctic-specific age equation cannot be used to constrain the ages of sediments from the Yermak Plateau.

These results generally support the rates of AAR determined for other deep-sea (cold bottom water) sites, further highlighting the peculiar high rate of racemization indicated by previous analyses of central Arctic sediments. For example, previously published (Kaufman et al., 2008) mean D/L Asp values for $N$. pachyderma samples from a central Arctic core from the Lomonosov Ridge (96/12-1PC) are around 0.4 for samples dated to $85-123 \mathrm{ka}$. The globally calibrated age equation predicts approximate ages of $263 \mathrm{kyr}$ for this $\mathrm{D} / \mathrm{L}$ Asp value (with $\pm 15.8 \mathrm{kyr}$ error, assuming an uncertainty of $6 \%$, typical of mean $\mathrm{D} / \mathrm{L}$ values in this study), and samples with similar $\mathrm{D} / \mathrm{L}$ values from the Yermak Plateau would date to around $232 \pm 14 \mathrm{ka}$. The considerable differences could indicate different post-depositional temperatures, variable sedimentation rates, diagenetic processes, issues with sample handling, storage, and processing or may point towards errors in the existing age models of central Arctic sediments. Further studies are clearly required to investigate these options.

AAR ages based on D/L Asp values and the globally calibrated AAR curve strongly correlate with the independent ages of Wiers et al. (2019) for both species (Fig. 9); however, there is a significant scatter in AAR ages older than $\sim 130 \mathrm{ka}$. Excluding all samples with stratigraphically reversed D/L Asp values (regardless of whether there is an overlap within $2 \sigma$ errors or not) increases the correlation coefficient $(r)$ to 0.96 in N. pachyderma and to 0.99 in C. neoteretis samples. While well-correlated, the globally calibrated age equation slightly ( $\sim$ on average $2 \%$ ) underestimates the ages of $N$. pachyderma samples, with the highest level of agreement between the ages observed in core PS92/45-2. The ages of $C$. neoteretis samples are mostly underestimated - on average by $32 \%$. This is expected considering the lower racemization rates of $C$. neoteretis observed in this study (approximately $16 \%$ slower than N. pachyderma). Both sets of data are coupled with high values of scatter, with differences between the modelled ages and the ages based on Wiers et al. (2019) reaching over $50 \%$ of the sample age in some cases. Nevertheless, the globally calibrated age equation provides a reliable age approximation for our Arctic Ocean sediments, 
Table 4. Independent sample ages based on Wiers et al. (2019) and sample ages and uncertainties based on the globally calibrated age equation of Kaufman et al. (2013) and the Arctic-specific age equation of Kaufman et al. (2008) based on mean D/L values of Asp and Glu.

\begin{tabular}{|c|c|c|c|c|c|c|c|}
\hline Lab ID & Core & $\begin{array}{r}\text { Depth } \\
\text { (mb.s.f.) }\end{array}$ & $\begin{array}{r}\text { Age (ka) based } \\
\text { on Wiers } \\
\text { et al. } \\
(2019)\end{array}$ & $\begin{array}{r}\text { Age Asp } \\
\text { Kaufman } \\
\text { et al. } \\
(2013)(\mathrm{ka})\end{array}$ & $\begin{array}{r}\text { Age Asp } \\
\text { Kaufman } \\
\text { et al. } \\
(2008)(\mathrm{ka})\end{array}$ & $\begin{array}{r}\text { Age Glu } \\
\text { Kaufman } \\
\text { et al. } \\
(2013)(\mathrm{ka})\end{array}$ & $\begin{array}{r}\text { Age Glu } \\
\text { Kaufman } \\
\text { et al. } \\
(2008)(\mathrm{ka})\end{array}$ \\
\hline \multicolumn{8}{|c|}{ Neogloboquadrina pachyderma } \\
\hline 15544 & PS92/39-2 & 0.20 & 6.7 & $6.7 \pm$ & 7.3 & 14.2 & 15.0 \\
\hline 15546 & PS92/39-2 & 1.50 & 30.8 & $51.0 \pm 3.9$ & $33.4 \pm 2.6$ & $36.7 \pm 4.5$ & $27.5 \pm 3.4$ \\
\hline 15547 & PS92/39-2 & 3.00 & 64.2 & $68.8 \pm 6.7$ & $41.9 \pm 4.1$ & $64.7 \pm 13.2$ & $39.7 \pm 8.1$ \\
\hline 15548 & PS92/39-2 & 3.80 & 80.4 & $50.3 \pm 3.5$ & $33.1 \pm 2.3$ & $50.2 \pm 3.2$ & $34.8 \pm 5.5$ \\
\hline 15549 & PS92/39-2 & 5.81 & 126.3 & $87.4 \pm 18.7$ & $50.1 \pm 10.9$ & $83.2 \pm 29.9$ & $44.1 \pm 14.0$ \\
\hline 15550 & PS92/39-2 & 6.51 & 139.2 & $128.1 \pm 5.6$ & $66.7 \pm 2.9$ & $161.8 \pm 19.5$ & $74.7 \pm 7.3$ \\
\hline 15551 & PS92/39-2 & 7.21 & 150.8 & $112.6 \pm 5.7$ & $60.6 \pm 3.1$ & $102.5 \pm 11.6$ & $49.3 \pm 6.7$ \\
\hline 15552 & PS92/39-2 & 8.31 & 168.5 & $96.4 \pm 6.8$ & $53.9 \pm 3.8$ & $83.2 \pm 10.9$ & $44.7 \pm 6.0$ \\
\hline 15553 & PS92/39-2 & 8.41 & 170.1 & $146.3 \pm 7.5$ & $73.7 \pm 3.8$ & $199.2 \pm 27.1$ & $87.6 \pm 6.7$ \\
\hline 16814 & PS92/45-2 & 1.20 & 29.8 & $26.9 \pm 1.7$ & $20.7 \pm 1.3$ & $40.1 \pm 4.2$ & $29.2 \pm 3.1$ \\
\hline 16815 & PS92/45-2 & 1.59 & 39.5 & $29.2 \pm 1.2$ & $22.0 \pm 0.9$ & $39.0 \pm 3.2$ & $28.6 \pm 2.4$ \\
\hline 16817 & PS92/45-2 & 3.12 & 90.1 & $90.3 \pm 5.5$ & $51.4 \pm 3.3$ & $104.6 \pm 19.2$ & $53.4 \pm 11.6$ \\
\hline 16818 & PS92/45-2 & 4.13 & 147.8 & $167.6 \pm 6.8$ & $81.7 \pm 3.3$ & $244.7 \pm 23.6$ & $93.4 \pm 9.0$ \\
\hline 17531 & PS92/45-2 & 4.45 & 171.8 & $186.2 \pm 13.6$ & $88.3 \pm 6.5$ & $303.8 \pm 38.0$ & $102.1 \pm 15.9$ \\
\hline 16819 & PS92/45-2 & 4.73 & 194.9 & $194.3 \pm 12.3$ & $91.2 \pm 5.8$ & $292.1 \pm 24.7$ & $104.7 \pm 8.9$ \\
\hline 16822 & PS92/54-1 & 1.79 & 40.1 & $18.1 \pm 1.2$ & $15.4 \pm 1.0$ & $25.7 \pm 3.6$ & $21.4 \pm 2.7$ \\
\hline 16826 & PS92/54-1 & 4.66 & 132.3 & $253.9 \pm 6.4$ & $111.5 \pm 2.8$ & $445.6 \pm 19.9$ & $137.4 \pm 6.1$ \\
\hline 16827 & PS92/54-1 & 4.94 & 135.8 & $209.5 \pm 18.4$ & $96.5 \pm 8.7$ & $296.0 \pm 43.6$ & $92.6 \pm 21.2$ \\
\hline 16828 & PS92/54-1 & 5.10 & 137.8 & $167.6 \pm 8.7$ & $81.7 \pm 4.3$ & $280.8 \pm 30.2$ & $102.1 \pm 11.0$ \\
\hline \multicolumn{8}{|c|}{ Cassidulina neoteretis } \\
\hline 17315 & PS92/45-2 & 1.04 & 25.4 & $6.7 \pm 0.2$ & & $4.4 \pm 0.3$ & \\
\hline 17316 & PS92/45-2 & 1.39 & 34.5 & $15.6 \pm$ & & $13.6 \pm-$ & \\
\hline 17317 & PS92/45-2 & 1.59 & 39.5 & $18.1 \pm 1.1$ & & $13.6 \pm 1.5$ & \\
\hline 17318 & PS92/45-2 & 1.75 & 43.5 & $26.5 \pm$ & & $24.8 \pm-$ & \\
\hline 17319 & PS92/45-2 & 3.12 & 90.1 & $82.7 \pm 6.3$ & & $64.7 \pm 4.4$ & \\
\hline 17320 & PS92/45-2 & 4.17 & 150.8 & $161.8 \pm 8.1$ & & $193.1 \pm 20.5$ & \\
\hline 17321 & PS92/45-2 & 4.45 & 171.8 & $85.5 \pm 6.8$ & & $175.6 \pm 28.5$ & \\
\hline 17322 & PS92/54-1 & 1.47 & 34.2 & $20.9 \pm 1.4$ & & $23.0 \pm 3.7$ & \\
\hline 17323 & PS92/54-1 & 1.79 & 40.1 & $14.1 \pm 0.4$ & & $13.6 \pm 0.7$ & \\
\hline 17324 & PS92/54-1 & 4.66 & 132.3 & $131.9 \pm 5.0$ & & $208.5 \pm 29.1$ & \\
\hline 17325 & PS92/54-1 & 4.94 & 135.8 & $140.9 \pm 7.3$ & & $218.0 \pm 23.4$ & \\
\hline 17326 & PS92/54-1 & 5.10 & 137.8 & $113.8 \pm 4.5$ & & $178.5 \pm 17.3$ & \\
\hline
\end{tabular}

when D/L Asp values from N. pachyderma samples are utilized.

\section{Conclusions}

The extent of racemization of Asp and Glu increases with increasing age in both N. pachyderma and C. neoteretis samples and is higher in $N$. pachyderma than in C. neoteretis from the same stratigraphic levels.

The globally calibrated age equation of Kaufman et al. (2013) provides a reliable age control for sediments from the Yermak Plateau. The Arctic-specific calibrated age equation of Kaufman et al. (2008) does not support the indepen- dent age-depth model in this area, and is not applicable to sediments from the Yermak Plateau.

Ages calculated with the globally calibrated age equation of Kaufman et al. (2013) show the highest level of agreement with sample ages when $\mathrm{D} / \mathrm{L}$ Asp values from $N$. pachyderma samples are used. Ages obtained using the globally calibrated age equation and $\mathrm{D} / \mathrm{L}$ Asp values in $C$. neoteretis samples consistently appear younger (on average by $32 \%$ ) than the independent ages, as expected given the lower rate of AAR in this species.

The results highlight the need for further studies to test and explain the origin of the higher racemization rates in 
foraminifera reported in previous studies from central Arctic sediments.

Data availability. The results of amino acid analysis of all subsamples are available in the digital Supplement, and archived at the World Data Service for Paleoclimatology (https://www.ncdc.noaa. gov/paleo-search/study/27812, last access: 15 November 2019; West et al., 2019). 


\section{Appendix A}

Prior to alignment, the $\mathrm{kARM} / \mathrm{k}$ time series and the $\delta^{18} \mathrm{O}_{\mathrm{LR}}$ stack were rescaled between -1 and 1 to improve comparability. The alignment function is then inferred at any point on the sediment core depth scale by a linear interpolation between three proposed depth-age models: a starting node, an ending node, and a perturbed node at a random location between the starting and ending nodes. The nodes strictly follow depth-age paths that do not violate the principle of superposition in order to ensure a monotonic relationship between the depth of the sediment core and the age of the $\delta^{18} \mathrm{O}_{\mathrm{LR}}$ stack. The algorithm determines the set of nodes that give a good alignment between the $\mathrm{kARM} / \mathrm{k}$ time series and the $\delta^{18} \mathrm{O}_{\mathrm{LR}}$ stack as defined by a small residual standard deviation and a high coefficient of correlation. As an additional condition, we require that the gradient of the depthage alignment function should be reasonably smooth, hence assuming that at our coring sites sedimentation rates have not undergone excessively rapid shifts or large fluctuations.

The requirement of a good match between the kARM/k records and the $\delta^{18} \mathrm{O}_{\mathrm{LR}}$ stack and a smooth alignment function is here devised in a Bayesian formulation sensitive to specification of a conjugate prior distribution and a conjugate likelihood distribution of the alignment function. The priors specify (i) the age distribution of the first and last kARM/k values on the $\delta^{18} \mathrm{O}_{\mathrm{LR}}$ age scale (here set as non-informative uniform ranging over $10 \mathrm{kyr}$ ) and (ii) the degree of autocorrelation of the sedimentation rates (here set as truncated uniform between $-50 \%$ and $+50 \%$ ). The latter dictates how much the accumulation rate of a particular depth depends on the depth above it, which in turn controls the gradient of the depth-age alignment function. The likelihood distribution of the alignment function weighs the competing needs of small standard deviations of the data residuals and a high correlation between the $\mathrm{kARM} / \mathrm{k}$ and the $\delta^{18} \mathrm{O}_{\mathrm{LR}}$ values. Finally, a conditional posterior distribution of alignment functions proportional to the product of prior and likelihood is inferred. Calculation of the posterior proceeds by sampling an initial value for each unknown parameter from the associated prior distributions using a reversible jump Markov chain Monte Carlo (MCMC) sampling (Vihola, 2012). In the alignment problem posed here, the automated MCMC method consists of the following steps. Starting from an initial age for the first and last $\mathrm{kARM} / \mathrm{k}$ values on the $\delta^{18} \mathrm{O}_{\mathrm{LR}}$ timescale that defines an initial match between the $\mathrm{kARM} / \mathrm{k}$ and $\delta^{18} \mathrm{O}_{\mathrm{LR}}$ time series, and by setting an initial value for the rate of sedimentation, it continues by

1. proposing a new "candidate" alignment function by adding a new depth-age node at a random location between the starting and ending nodes along the depth scale of the sediment core.

2. accepting or rejecting the candidate alignment function according to its posterior probability using the
Metropolis-Hastings algorithm (Metropolis et al., 1953; Hastings, 1970), whereby the posterior probability is higher for alignment functions that yield a closer match (i.e. a smaller residual standard deviation and a high coefficient of correlation).

3. Repeat from step 1 for $10^{6}$ iterations. 
Supplement. The supplement related to this article is available online at: https://doi.org/10.5194/gchron-1-53-2019-supplement.

Author contributions. GW analysed the data and prepared the paper with contributions from all authors. DSK contributed interpretation of AAR results, FM provided age model tuning, MF, JM, and JW contributed material, chronological and oceanographic interpretation, and MO coordinated the study and contributed palaeoceanographic interpretation.

Competing interests. The authors declare that they have no conflict of interest.

Acknowledgements. We thank the Captain and the crew of RV Polarstern, and the participants of the TRANSSIZ expedition for facilitating data collection during PS92. Katherine Whitacre provided laboratory support at the Amino Acid Geochronology Laboratory, Northern Arizona University.

Financial support. This research has been supported by the Swedish Research Council (grant DNR-2016-05092), the National Science Foundation (grant NSF-1855381), and the Alfred-WegenerInstitut (grant AWI_PS92_00).

Review statement. This paper was edited by Kirsty Penkman and reviewed by three anonymous referees.

\section{References}

Alexanderson, H., Backman, J., Cronin, T. M., Funder, S., Ingolfsson, O., Jakobsson, M., Landvik, J. Y., Löwemark, L., Mangerud, J., März, C., and Möller, P.: An Arctic perspective on dating MidLate Pleistocene environmental history, Quaternary Sci. Rev., 92, 9-31, https://doi.org/10.1016/j.quascirev.2013.09.023, 2014.

Backman, J., Jakobsson, M., Løvlie, R., Polyak, L., and Febo, L. A.: Is the central Arctic Ocean a sediment starved basin?, Quaternary Sci. Rev., 23, 1435-1454, https://doi.org/10.1016/j.quascirev.2003.12.005, 2004.

Backman, J., Jakobsson, M., Frank, M., Sangiorgi, F., Brinkhuis, H., Stickley, C., O’Regan, M., Løvlie, R., Pälike, H., Spofforth, D., and Gattacecca, J.: Age model and core-seismic integration for the Cenozoic Arctic Coring Expedition sediments from the Lomonosov Ridge, Paleoceanography, 23, PA1S03, https://https://doi.org/10.1029/2007PA001476, 2008.

Bergsten, H.: Recent benthic foraminifera of a transect from the North Pole to the Yermak Plateau, eastern central Arctic Ocean, Mar. Geol., 119, 251-267, https://doi.org/10.1016/00253227(94)90184-8, 1994.

Carstens, J. and Wefer, G.: Recent distribution of planktonic foraminifera in the Nansen Basin, Arctic Ocean, Deep Sea Res.Part A, 39, S507-S524, https://doi.org/10.1016/s01980149(06)80018-x, 1992.
Carstens, J., Hebbeln, D., and Wefer, G.: Distribution of planktic foraminifera at the ice margin in the Arctic (Fram Strait), Mar. Micropaleontol., 29, 257-269, https://doi.org/10.1016/s03778398(96)00014-x, 1997.

Clark, D.: Magnetic Reversals and Sedimentation Rates in the Arctic Ocean, GSA Bull., 81, 3129-3134, https://doi.org/10.1130/00167606(1970)81[3129:MRASRI]2.0.CO;2, 1970.

Goodfriend, G. A., Brigham-Grette, J., and Miller, G. H.: Enhanced age resolution of the marine Quaternary record in the Arctic using aspartic acid racemization dating of bivalve shells, Quaternary Res., 45, 176-187, https://doi.org/10.1006/qres.1996.0018, 1996.

Greco, M., Jonkers, L., Kretschmer, K., Bijma, J., and Kucera, M.: Depth habitat of the planktonic foraminifera Neogloboquadrina pachyderma in the northern high latitudes explained by sea-ice and chlorophyll concentrations, Biogeosciences, 16, 3425-3437, https://doi.org/10.5194/bg-16-3425-2019, 2019.

Haake, F. W. and Pflaumann, U. W. E.: Late Pleistocene foraminiferal stratigraphy on the Vøring Plateau, Norwegian Sea, Boreas, 18, 343-356, https://doi.org/10.1111/j.15023885.1989.tb00410.x, 1989.

Hastings, W. K.: Monte Carlo sampling methods using Markov chains and their applications, Biometrika, 57, 97-109, https://doi.org/10.1093/biomet/57.1.97, 1970.

Hearty, P. J., O’Leary, M. J., Kaufman, D. S., Page, M. C., and Bright, J.: Amino acid geochronology of individual foraminifer (Pulleniatina obliquiloculata) tests, north Queensland margin, Australia: a new approach to correlating and dating Quaternary tropical marine sediment cores, Paleoceanography, 19, PA4022, https://doi.org/10.1029/2004PA001059, 2004.

Jakobsson, M., Løvlie, R., Arnold, E. M., Backman, J., Polyak, L., Knutsen, J. O., and Musatov, E.: Pleistocene stratigraphy and paleoenvironmental variation from Lomonosov Ridge sediments, central Arctic Ocean, Global Planet. Change, 31, 1-22, https://doi.org/10.1016/s0921-8181(01)00110-2, 2001.

Jakobsson, M., Mayer, L., Coakley, B., Dowdeswell, J. A., Forbes, S., Fridman, B., Hodnesdal, H., Noormets, R., Pedersen, R., Rebesco, M., and Schenke, H. W.: The international bathymetric chart of the Arctic Ocean (IBCAO) version 3.0., Geophys Res. Lett., 39, L12609, https://doi.org/10.1029/2012GL052219, 2012.

Jones, E. P.: Circulation in the arctic ocean, Polar Res., 20, 139-146, https://doi.org/10.1111/j.1751-8369.2001.tb00049.x, 2001.

Kaufman, D. S.: Temperature sensitivity of aspartic and glutamic acid racemization in the foraminifera Pulleniatina, Quaternary Geochronol., 1, 188-207, https://doi.org/10.1016/j.quageo.2006.06.008, 2006.

Kaufman, D. S. and Manley, W. F.: A new procedure for determining DL amino acid ratios in fossils using reverse phase liquid chromatography, Quaternary Sci. Rev., 17, 987-1000, https://doi.org/10.1016/s0277-3791(97)00086-3, 1998.

Kaufman, D. S., Polyak, L., Adler, R., Channell, J. E., and Xuan, C.: Dating late Quaternary planktonic foraminifer Neogloboquadrina pachyderma from the Arctic Ocean using amino acid racemization, Paleoceanography, 23, PA3224, https://https://doi.org/10.1029/2008PA001618, 2008.

Kaufman, D. S., Cooper, K., Behl, R., Billups, K., Bright, J., Gardner, K., Hearty, P., Jakobsson, M., Mendes, 
I., O'Leary, M., and Polyak, L.: Amino acid racemization in mono-specific foraminifera from Quaternary deep-sea sediments, Quaternary Geochronol., 16, 50-61, https://doi.org/10.1016/j.quageo.2012.07.006, 2013.

King, K. and Neville, C.: Isoleucine epimerization for dating marine sediments: importance of analyzing monospecific foraminiferal samples, Science, 195, 1333-1335, https://doi.org/10.1126/science.195.4284.1333, 1977.

Kosnik, M. A. and Kaufman, D. S.: Identifying outliers and assessing the accuracy of amino acid racemization measurements for geochronology: II. Data screening, Quaternary Geochronol., 3, 328-341, https://doi.org/10.1016/j.quageo.2008.04.001, 2008.

Kremer, A., Stein, R., Fahl, K., Ji, Z., Yang, Z., Wiers, S., Matthiessen, J., Forwick, M., Löwemark, L., O'Regan, M., and Chen, J.: Changes in sea ice cover and ice sheet extent at the Yermak Plateau during the last $160 \mathrm{ka}$ - Reconstructions from biomarker records, Quaternary Sci. Rev., 182, 93-108, https://doi.org/10.1016/j.quascirev.2017.12.016, 2018.

Lisiecki, L. E. and Raymo, M. E.: A Pliocene-Pleistocene stack of 57 globally distributed benthic $\delta^{18} \mathrm{O}$ records, Paleoceanography, 20, PA1003, https://doi.org/10.1029/2004PA001071, 2005.

Lougheed, B. C., Metcalfe, B., Ninnemann, U. S., and Wacker, L.: Moving beyond the age-depth model paradigm in deepsea palaeoclimate archives: dual radiocarbon and stable isotope analysis on single foraminifera, Clim. Past, 14, 515-526, https://doi.org/10.5194/cp-14-515-2018, 2018.

Macko, S. A. and Aksu, A. E.: Amino acid epimerization in planktonic foraminifera suggests slow sedimentation rates for Alpha Ridge, Arctic Ocean, Nature, 322, 730-732, https://doi.org/10.1038/322730a0, 1986.

Malinverno, A.: Data report: Monte Carlo correlation of sediment records from core and downhole log measurements at Sites U1337 and U1338 (IODP Expedition 321), edited by: Pälike, H., Lyle, M., Nishi, H., Raffi, I., Gamage, K., Klaus, A., and the Expedition 320/321 Scientists, Proc. IODP, 320/321: Tokyo (Integrated Ocean Drilling Program Management International, Inc.), https://doi.org/10.2204/iodp.proc.320321.207.2013, 2013.

Martinson, D. G., Pisias, N. G., Hays, J. D., Imbrie, J., Moore, T. C., and Shackleton, N. J.: Age dating and the orbital theory of the ice ages: Development of a high-resolution 0 to 300,000-year chronostratigraphy 1, Quaternary Res., 27, 1-29, https://doi.org/10.1016/0033-5894(87)90046-9, 1987.

Metropolis, N., Rosenbluth, A. W., Rosenbluth, M. N., Teller, A. H., and Teller, E.: Equation of state calculations by fast computing machines, J. Chem. Phys., 21, 1087-1092, https://doi.org/10.1063/1.1699114, 1953.

Muschitiello, F.: Deglacial impact of the Scandinavian Ice Sheet on the North Atlantic climate system (Doctoral dissertation, Department of Geological Sciences), 2016.

Muschitiello, F., Pausata, F. S., Watson, J. E., Smittenberg, R. H., Salih, A. A., Brooks, S. J., Whitehouse, N. J., Karlatou-Charalampopoulou, A., and Wohlfarth, B.: Fennoscandian freshwater control on Greenland hydroclimate shifts at the onset of the Younger Dryas, Nat. Commun., 6, 8939, https://doi.org/10.1038/ncomms9939, 2015.

Muschitiello, F., D’Andrea, W. J., Schmittner, A., Heaton, T. J., Balascio, N. L., DeRoberts, N., Caffee, M. W., Woodruff, T. E., Welten, K. C., Skinner, L. C., and Simon, M. H.: Deep-water circulation changes lead North Atlantic climate during deglacia- tion, Nat. Commun., 10, 1272, https://doi.org/10.1038/s41467019-09237-3, 2019.

Okay, N. and Crane, K.: Thermal rejuvenation of the Yermak Plateau, Mar. Geophys. Res., 15, 243-263, https://doi.org/10.1007/bf01982384, 1993.

O’Regan, M., Moran, K., Backman, J., Jakobsson, M., Sangiorgi, F., Brinkhuis, H., Pockalny, R., Skelton, A., Stickley, C., Koç, N., and Brumsack, H. J.: Mid-Cenozoic tectonic and paleoenvironmental setting of the central Arctic Ocean, Paleoceanography, 23, PA1S20, https://doi.org/10.1029/2007PA001559, 2008.

Pados, T. and Spielhagen, R. F.: Species distribution and depth habitat of recent planktic foraminifera in Fram Strait, Arctic Ocean, Polar Res., 33, 22483, https://doi.org/10.3402/polar.v33.22483, 2014.

Polyak, L. and Solheim, A.: Late-and postglacial environments in the northern Barents Sea west of Franz Josef Land, Polar Res., 13, 197-207, https://doi.org/10.1111/j.17518369.1994.tb00449.x, 1994.

Sejrup, H. P., Miller, G. H., Brigham-Grette, J., Løvlie, R., and Hopkins, D.: Amino acid epimerization implies rapid sedimentation rates in Arctic Ocean cores, Nature, 310, 772-775, https://doi.org/10.1038/310772a0, 1984.

Sejrup, H. P. and Haugen, J. E.: Amino acid diagenesis in the marine bivalve Arctica islandica Linné from northwest European sites: only time and temperature?, J. Quaternary Sci., 9, 301-309, https://doi.org/10.1002/jqs.3390090402, 1994.

Shephard, G. E., Wiers, S., Bazhenova, E., Pérez, L. F., Mejía, L. M., Johansson, C., Jakobsson, M., and O'Regan, M.: A North Pole thermal anomaly? Evidence from new and existing heat flow measurements from the central Arctic Ocean, J. Geodyn., 118, 166-181, https://doi.org/10.1016/j.jog.2018.01.017, 2018.

Ślubowska, M. A., Koç, N., Rasmussen, T. L., and KlitgaardKristensen, D.: Changes in the flow of Atlantic water into the Arctic Ocean since the last deglaciation: evidence from the northern Svalbard continental margin, 80 N, Paleoceanography, 20, PA4014, https://doi.org/10.1029/2005PA001141, 2005.

Stein, R.: The great challenges in Arctic Ocean paleoceanography, IOP Conf. Ser. Earth Environ. Sci., 14, 012001, https://doi.org/10.1088/1755-1315/14/1/012001, 2011.

Vihola, M.: Robust adaptive Metropolis algorithm with coerced acceptance rate, Stat. Comput., 22, 997-1008, https://doi.org/10.1007/s11222-011-9269-5, 2012.

Wehmiller, J. F.: Interlaboratory comparison of amino acid enantiomeric ratios in fossil Pleistocene mollusks, Quaternary Res., 22, 109-120, https://doi.org/10.1016/0033-5894(84)90010-3, 1984.

West, G., Kaufman, D. S., Muschitiello, F., Forwick, M., Matthiessen, J., Wollenburg, J., and O'Regan, M.: Yermak Plateau, Arctic Ocean 227 ka Foraminifer Amino Acid Racemization Data, NOAA, available at: https://www.ncdc.noaa.gov/ paleo-search/study/27812, last access: 15 November 2019.

Wiers, S., Snowball, I., O'Regan, M., and Almqvist, B.: Late Pleistocene Chronology of Sediments from the Yermak Plateau and Uncertainty in Dating Based on Geomagnetic Excursions, Geochem. Geophys. Geosys., 20, 3289-3310, https://doi.org/10.1029/2018gc007920, 2019.

Wohlfarth, B., Luoto, T. P., Muschitiello, F., Väliranta, M., Björck, S., Davies, S. M., Kylander, M., Ljung, K., Reimer, P. J., and Smittenberg, R. H.: Climate and environment in south- 
west Sweden 15.5-11.3 cal. ka BP, Boreas, 47, 687-710, https://doi.org/10.1111/bor.12310, 2018.

Wollenburg, J. E. and Mackensen, A.: Living benthic foraminifers from the central Arctic Ocean: faunal composition, standing stock and diversity, Mar. Micropaleontol., 34, 153-185, https://doi.org/10.1016/s0377-8398(98)00007-3, 1998.

Wollenburg, J. E., Kuhnt, W., and Mackensen, A.: Changes in Arctic Ocean paleoproductivity and hydrography during the last 145 kyr: the benthic foraminiferal record, Paleoceanogr. Paleocl., 16, 65-77, 2001.
Wollenburg, J. E., Knies, J., and Mackensen, A.: High-resolution paleoproductivity fluctuations during the past $24 \mathrm{kyr}$ as indicated by benthic foraminifera in the marginal Arctic Ocean, Palaeogeogr. Palaeocl., 204, 209-238, https://doi.org/10.1016/s00310182(03)00726-0, 2004.

Xuan, C., Channell, J. E., Polyak, L., and Darby, D. A.: Paleomagnetism of Quaternary sediments from Lomonosov Ridge and Yermak Plateau: implications for age models in the Arctic Ocean, Quaternary Sci. Rev., 32, 48-63, https://doi.org/10.1016/j.quascirev.2011.11.015, 2012. 